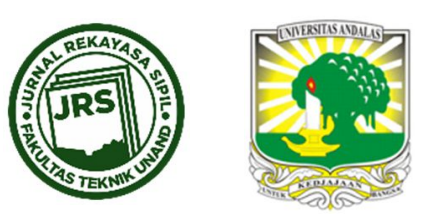

\title{
IDENTIFIKASI FAKTOR PENYEBAB KETERLAMBATAN PELAKSANAAN PROYEK INFRASTRUKTUR SUMBERDAYA AIR DI KABUPATEN SOLOK
}

\author{
FIRDAUS ${ }^{1}$, BENNY HIDAYAT ${ }^{1}$, BAMBANG ISTIJONO ${ }^{1}$ \\ ${ }^{1}$ Jurusan Teknik Sipil, Universitas Andalas, Padang, Sumatera Barat \\ "Corresponding author: $ه$ bennyhidayat@eng.unand.ac.id
}

Naskah diterima : 26 Desember 2019. Disetujui: 11 Agustus 2020

\begin{abstract}
ABSTRAK
Kabupaten Solok adalah daerah pertanian dan lumbung penghasil beras di Provinsi Sumatera Barat. Untuk menjaga produksi beras dan pertanian pemerintah kabupaten melaksanakan berbagai proyek sumberdaya air untuk menunjang produksi pertanian tersebut. Pelaksanaan proyek tersebut memperlihatkan adanya keterlambatan proyek. Penelitian ini bertujuan untuk mengidentifikasi sumber-sumber penyebab keterlambatan proyek infrastruktur sumberdaya air di Kabupaten Solok. Penelitian ini menggunakan metoda survey kuesioner dan total ada 75 responden ang teriri dari kontraktor, konsultan perencana, konsultan pengawas, PPTK, dan PPK. Hasil kuesioner memperliahtkan dari 17 buah faktor yang ditinjau didapatkan 5 faktor utama yang berpengaruh terhadap keterlambatan, yaitu pembebasan tanah (nilai rata-rata 4,53), pengaruh cuaca (rata-rata 4,53 ), tidak ada sosialisasi dengan instansi terkait (rata-rata 4,37), lokasi proyek sulit dijangkau (ratarata 4,28), dan manajemen pengawasan proyek yang buruk (rata-rata 4,20).
\end{abstract}

Kata kunci : keterlambatan proyek, sumberdaya air, faktor keterlambatan, pembebasan lahan, kabupaten solok

\section{PENDAHULUAN}

Kabupaten Solok merupakan salah satu daerah yang dikenal sebagai lumbung padi dan penghasil sayuran terbanyak dan terbaik di Provinsi Sumatera Barat dengan luas areal pertanian 62.471 Ha (BPS Kab. Solok, 2017). Sebagian besar wilayah produktif merupakan hamparan sawah dan ladang yang ditanami padi dan sayur-sayuran. Kegiatan pertanian merupakan kegiatan utama sebagian besar penduduk yang menggantungkan hidupnya dari hasil-hasil pertanian ini. Luas lahan untuk sawah sawah lebih kurang 6.30\% dari luas daerah dan merupakan areal sawah terbesar di provinsi Sumatera Barat (Pemkab. Solok, 2009).

Sebagai daerah penghasil beras terbesar, Pemerintah Kabupaen Solok melalui Dinas Pekerjaan Umum melaksanakan berbagai proyek infrastruktur sumberdaya air yang 
bertujuan menunjang ketersedian dan ketahanan air untuk area pertanian, untuk menjaga Kabupaten Solok sebagai daerah penghasil beras. Dalam pelaksanaan proyek tersebut terdapat hambatan-hambatan yang menyebabkan target biaya dan durasi proyek tidak tercapai. Data pada Tabel 1 diperoleh dari bagian sumberdaya air Dinas Pekerjaan Umum Kabupaten Solok, memperlihatkan proyek-proyek yang terlaksana pada tahun 2015.

Tabel 1. Kegiatan Proyek Sumberdaya Air Kab. Solok 2015

\begin{tabular}{lllrrr}
\hline $\begin{array}{c}\text { N } \\
\mathbf{o}\end{array}$ & \multicolumn{1}{c}{ Nama Kegiatan } & $\begin{array}{c}\text { Kontrak Awal } \\
\text { (Rp.) }\end{array}$ & $\begin{array}{c}\text { Kontrak Akhir/ } \\
\text { Addendum (Rp.) }\end{array}$ & $\begin{array}{c}\text { Waktu } \\
\text { Rencana }\end{array}$ & $\begin{array}{r}\text { Waktu } \\
\text { Aktual }\end{array}$ \\
\hline \multirow{2}{*}{$\begin{array}{l}\text { Perbaikan tebing sungai Btg. } \\
\text { Sapan Kayu Manang }\end{array}$} & $\begin{array}{c}247.500 .000,00 \\
2\end{array}$ & $272.250 .000,00$ & 120 & 125 \\
\hline \multirow{2}{*}{$\begin{array}{l}\text { Perbaikan tebing sungai Btg. } \\
\text { Paninggahan }\end{array}$} & $\begin{array}{l}\text { Perbaikan tebing sungai Btg. } \\
\text { Imang }\end{array}$ & $726.000 .000,00$ & $798.600 .000,00$ & 120 & 132 \\
\hline 4 & $\begin{array}{l}\text { Perbaikan tebing sungai Btg. } \\
\text { Sumani }\end{array}$ & $255.000 .000,00$ & $280.500 .000,00$ & 90 & 100 \\
\hline 5 & Bandar Muaro Danau & $193.050 .000,00$ & $212.355 .000,00$ & 120 & 121 \\
\hline 6 & Bandar Karang & $196.875 .000,00$ & $216.562 .500,00$ & 90 & 118 \\
\hline 7 & Bandar Lawas Sirukam & $195.750 .000,00$ & $215.325 .000,00$ & 90 & 93 \\
\hline 8 & Bandar Sawah Taluak & $193.050 .000,00$ & $212.355 .000,00$ & 90 & 90 \\
\hline 9 & Bandar Sawah Pinang & $195.255 .000,00$ & $214.780 .500,00$ & 90 & 90 \\
\hline 10 & Bandar Sawah Cangkiang & $184.500 .000,00$ & $202.950 .000,00$ & 90 & 90 \\
\hline 11 & Bandar Gantiang & $199.125 .000,00$ & $219.037 .500,00$ & 90 & 93 \\
\hline 12 & Bandar Pompanisasi I, II, III & $331.100 .000,00$ & $364.210 .000,00$ & 90 & 100 \\
\hline 13 & Bandar Lembang Murai & $223.196 .600,00$ & $245.516 .260,00$ & 90 & 90 \\
\hline 14 & Bandar Barusuang & $240.982 .500,00$ & $265.080 .750,00$ & 90 & 90 \\
\hline 15 & Bandar Guguk Bulek & $189.860 .000,00$ & $208.846 .000,00$ & 90 & 92 \\
\hline
\end{tabular}

Dari tabel di atas terlihat bahwa semua proyek yang dilaksanakan mengalami perbedaan antara biaya dan durasi akhir dengan biaya dan durasi rencana. Untuk waktu pelaksanaan proyek, sebagian besar proyek waktu pelaksanaan aktualnya lebih lama dari rencana awal atau terjadi keterlambatan dalam penyelesaian proyek.

Pelaksanaan proyek-proyek infrastruktur tersebut akan mempunyai pengaruh terhadap kesediaan air untuk area pertanian dan persawahan, sehingga keterlambatan proyek akan memberi pengaruh juga terhadap produksi pertanian. Dengan pertimbangan tersebut, penelitian ini bertujuan untuk mengidentifikasi sumber-sumber penyebab keterlambatan proyek infrastruktur sumberdaya air di Kabupaten Solok. Hasil identifikasi akan membantu dalam proses manajemen proyek selanjutnya sehingga keterlambatan proyek bisa dikurangi.

\section{KETERLAMBATAN PROYEK INFRASTRUKUTR}

Project Management Institute (PMI) mendefenisikan sebuah proyek sebagai "a temporary endeavour undertaken to create a unique product, service and result" (PMI, 2008). Defenisi teresebut memperlihatkan proyek mempunyai ciri sebagai kegiatan yang tidak tetap (temporary), dimana itu mengindikasikan proyek mempunyai durasi tertentu, dengan adanya waktu mulai dan waktu selesai proyek tertentu. Proyek selesai ketika tujuan proyek yang untuk menghasilkan produk atau jasa terpenuhi atau proyek bisa dihentikan ketika sudah bisa dipastikan tujuan proyek tidak akan bisa dicapai. Definisi proyek yang yang lain adalah karakteristik proyek mempunyai tujuan spesifik yang diselesaikan dengan spesifikasi tertentu, mempunyai tanggal mulai dan selesai, mempunyai batas pembiayaan, membutuhan sumberdaya manusia dan sumberdaya lainnya, dan kegiatan proyek bersifat multifungsional (Kerzner, 2009). Dari definisi proyek oleh PMI dan Kerzner di atas, jelas 
memperlihatkan bahwa kegiatan proyek mempunyai tujuan tertentu dan untuk mencapai tujuan tersebut ada batasan-batasan dalam pelaksanaannya. Faktor waktu menjadi salah satu parameter utama dalam sebuah proyek, proyek sudah mempunyai waktu yang tertentu yang sudah ditetapkan dan itu menjadi patokan untuk mengukur keberhasilan proyek.

Proyek konstruksi dilaksanakan dalam beberapa tahapan. Soeharto (1995) membagi kedalam empat tahapan, yaitu tahap konseptual, tahap perencanaan dan pemantapan, tahap iplementasi, dan tahap operasi. Tahapan pendahuluan berisi perumusan gagasan dan studi kelayakan, sementara tahapan perencanaan berupa kegiatan data dan keriteria berupa gambar dan spesifikasi pekerjaan. Kegiatan implementasi melaksanakan hasil dari tahapan perencanaan. Tahapan pelaksanaan pekerjaan ini saling berkait sehingga tahapan pelaksanaan akan dipengeruhu juga oleh tahapan sebelumnya yaitu tahapan perencanaan.

Tercapainya tujuan proyek akan dipengaruhi oleh kehadiran risiko proyek, yang bisa didefensisikan sebagai segala sesuatu yang akan menyebabkan kenaikan biaya, keterlambatan proyek dan ketidaksesuai kualitas. Proyek menjadi terlambat apabila terjadi dalam masa pelaksanaan proyek risiko proyek. Penelitian Hidayat and Rasadi (2014) membahas tentang risiko-risiko proyek konstruksi di Sumatera Barat, membagi proyek sebagai objek penelitian kedalam tahapan proyek, jenis proyek dan lokasi proyek (Tabel 2). Mereka mengidentifikasi risiko proyek yang terjadi dari 90 proyek yang mereka dapatkan dari berita surat kabar.

Tabel 2. Jumlah permasalahan proyek berdasarkan tipe proyek dan lokasi proyek (Hidayat \& Rasadi, 2014)

\begin{tabular}{|c|c|c|c|c|c|c|c|c|c|c|c|c|c|c|c|c|c|c|c|}
\hline \multirow{2}{*}{ Tahapan \& Permasalahan Proyek } & \multirow{2}{*}{ Total } & \multicolumn{3}{|c|}{ Jenis Proyek } & \multicolumn{15}{|c|}{ Lokasi Proyek (Kota/Kabupaten) } \\
\hline & & PA & PG & PJ & AGM & BKT & DHS & KSL & SLS & SLK & LPK & \begin{tabular}{|l|l|} 
PDG \\
\end{tabular} & PRM & PSM & PSB & PYK & PSS & SJJ & TDT \\
\hline \multicolumn{20}{|l|}{ 1. Pra-konstruksi } \\
\hline Tender & 23 & 4 & 12 & 7 & 4 & 3 & 1 & 0 & 0 & 0 & 3 & 9 & 0 & 1 & 0 & 1 & 1 & 0 & 0 \\
\hline Perencanaan tidak bagus & 11 & 5 & 1 & 5 & 2 & 0 & 0 & 0 & 1 & 0 & 1 & 3 & 0 & 1 & 1 & 1 & 0 & 0 & 1 \\
\hline Lahan & 17 & 4 & 3 & 10 & 2 & 3 & 0 & 0 & 1 & 1 & 1 & 6 & 1 & 1 & 1 & 0 & 0 & 0 & 0 \\
\hline $\mathrm{KKN}$ & 2 & 0 & 1 & 1 & 0 & 1 & 0 & 0 & 0 & 0 & 1 & 0 & 0 & 0 & 0 & 0 & 0 & 0 & 0 \\
\hline Hubungan Masyarakat & 7 & 2 & 2 & 3 & 1 & 0 & 0 & 0 & 0 & 0 & 1 & 4 & 0 & 0 & 1 & 0 & 0 & 0 & 0 \\
\hline Dana & 2 & 0 & 1 & 1 & 0 & 0 & 0 & 0 & 0 & 0 & 0 & 2 & 0 & 0 & 0 & 0 & 0 & 0 & 0 \\
\hline \multicolumn{20}{|l|}{ 2. Konstruksi } \\
\hline Penghentian pekerjaan & 2 & 0 & 0 & 2 & 0 & 0 & 0 & 0 & 0 & 0 & 1 & 0 & 0 & 1 & 0 & 0 & 0 & 0 & 0 \\
\hline Lemahnya pengawasan pekerjaan proyek & 7 & 3 & 1 & 3 & 1 & 0 & 1 & 0 & 1 & 0 & 0 & 1 & 0 & 0 & 0 & 2 & 0 & 1 & 0 \\
\hline Revisi desain & 5 & 2 & 0 & 3 & 1 & 0 & 0 & 0 & 0 & 0 & 3 & 1 & 0 & 0 & 0 & 0 & 0 & 0 & 0 \\
\hline Kesalahan dalam pengerjaan & 9 & 3 & 3 & 3 & 0 & 1 & 0 & 2 & 0 & 1 & 2 & 0 & 0 & 1 & 0 & 0 & 0 & 2 & 0 \\
\hline Penyedia Jasa bermasalah & 11 & 4 & 2 & 5 & 2 & 1 & 1 & 1 & 1 & 0 & 2 & 1 & 0 & 1 & 0 & 0 & 0 & 1 & 0 \\
\hline Material & 6 & 2 & 2 & 2 & 1 & 1 & 1 & 0 & 0 & 0 & 0 & 1 & 0 & 0 & 0 & 2 & 0 & 0 & 0 \\
\hline Lahan & 14 & 6 & 2 & 6 & 0 & 0 & 0 & 1 & 0 & 1 & 4 & 2 & 1 & 2 & 2 & 0 & 1 & 0 & 0 \\
\hline Korupsi & 4 & 2 & 1 & 1 & 0 & 1 & 1 & 0 & 0 & 0 & 2 & 0 & 0 & 0 & 0 & 0 & 0 & 0 & 0 \\
\hline Kontrak & 7 & 2 & 2 & 3 & 2 & 1 & 0 & 0 & 0 & 1 & 2 & 0 & 0 & 0 & 0 & 0 & 1 & 0 & 0 \\
\hline Hubungan Masyarakat & 12 & 9 & 2 & 1 & 2 & 0 & 0 & 0 & 0 & 1 & 2 & 3 & 0 & 0 & 3 & 0 & 0 & 1 & 0 \\
\hline Dana dan Anggaran & 12 & 4 & 3 & 5 & 0 & 0 & 2 & 0 & 0 & 0 & 6 & 2 & 0 & 0 & 0 & 1 & 0 & 1 & 0 \\
\hline Alam dan cuaca & 3 & 1 & 1 & 1 & 0 & 0 & 0 & 0 & 0 & 0 & 1 & 0 & 0 & 0 & 0 & 2 & 0 & 0 & 0 \\
\hline \multicolumn{20}{|l|}{ 3. Pasca-konstruksi } \\
\hline Konstruksi tidak berfungsi & 4 & 4 & 0 & 0 & 0 & 0 & 0 & 0 & 0 & 0 & 3 & 1 & 0 & 0 & 0 & 0 & 0 & 0 & 0 \\
\hline Kegagalan bangunan & 7 & 4 & 2 & 1 & 0 & 0 & 2 & 1 & 1 & 0 & 1 & 0 & 0 & 1 & 0 & 0 & 0 & 0 & 1 \\
\hline Sanksi & 4 & 2 & 1 & 1 & 1 & 0 & 0 & 0 & 0 & 0 & 0 & 2 & 0 & 0 & 0 & 0 & 0 & 1 & 0 \\
\hline Lahan & 1 & 1 & 0 & 0 & 1 & 0 & 0 & 0 & 0 & 0 & 0 & 0 & 0 & 0 & 0 & 0 & 0 & 0 & 0 \\
\hline Uji coba gagal & 1 & 1 & 0 & 0 & 0 & 0 & 0 & 0 & 0 & 0 & 0 & 0 & 0 & 0 & 0 & 0 & 0 & 1 & 0 \\
\hline Mutu akhir tidak sesuai & 6 & 2 & 1 & 3 & 0 & 0 & 0 & 0 & 1 & 0 & 1 & 1 & 0 & 0 & 1 & 1 & 0 & 1 & 0 \\
\hline \multicolumn{20}{|c|}{ Keterangan : Jenis proyek: $\mathrm{PA}=$ Proyek Air, $\mathrm{PG}=$ Proyek Gedung, $\mathrm{PJ}=$ Proyek Jalan } \\
\hline & Lokasi pr & & $A G M=$ & & Agam, & $\mathrm{BKT}=$ & Kota & Bukit & Tinggi, & & & Dharm & nasraye & $\mathrm{ya}, \mathrm{nol}$ & $=K a b$ & Solok & & & \\
\hline & $\begin{array}{l}S L S=K a \\
P S M=K a\end{array}$ & & $\begin{array}{l}\text { k Selat } \\
\text { aman, }\end{array}$ & $\begin{array}{l}\mathrm{n}, \mathrm{SL} \\
\mathrm{SB}=\mathrm{K}\end{array}$ & $\begin{array}{l}\text { K, Kota } \\
\text { ab.Pas }\end{array}$ & $\begin{array}{l}\text { Solok, } \\
\text { aman }\end{array}$ & $\begin{array}{l}\text { K, LPK } \\
\text { Barat, }\end{array}$ & $\begin{array}{l}=K a b . \\
\text { PYK }\end{array}$ & $\begin{array}{l}\text { Limap } \\
=\text { Kota }\end{array}$ & $\begin{array}{l}\text { ouluh } r \\
\text { Payak }\end{array}$ & $\begin{array}{l}\text { Kota, } \\
\text { uumbu }\end{array}$ & $\begin{array}{l}P D G=k \\
h, P S S\end{array}$ & $\begin{array}{l}\text { kota } P \\
S=K a b .\end{array}$ & $\begin{array}{l}\text { Padang } \\
\text { b.Pesis }\end{array}$ & $\begin{array}{l}\text { PRM } \\
\text { ir Sela }\end{array}$ & $\begin{array}{l}\text { A=kota } \\
\text { atan, }\end{array}$ & Pariar & & \\
\hline & $\mathrm{SJJ}=\mathrm{Kab}$ & a & ung, $\mathrm{T}$ & $\mathrm{T}=\mathrm{Kat}$ & o.Tanat & h Datar & & & & & & & & & & & & & \\
\hline
\end{tabular}


Hasil penelitian tersebut pada tabel di atas memperlihatkan bahwa ada perbedaan risiko berdasarkan tipe proyek. Proyek Sumberdaya air berdasarkan tabel tersebut memperlihatkan adanya risiko lahan dan perencanaan yang tidak bagus pada tahapan prakontruksi. Pada tahapan konstruksi risiko terbesar untuk proyek sumberdaya air berupa risiko hubungan dengan masrayakat dan risiko berkaitan dengan lahan. Dari sisi lokasi proyek, Kabupaten Solok juga ada dalam tabel hasil penelitian tersebut, walau pun hanya ada beberapa kejadian risiko proyek. Pada masa konstruksi terjadi kesalahan pengerjaan, penyedia jasa bermasalah, risiko lahan di Kabupaten Solok.

\section{METODOLOGI PENELITIAN}

Penelitian ini bertujuan untuk mengidentifikasi penyebab terjadinya proyek sumberdaya air di Kabupaten Solok. Penelitian mengadopsi penelitian kuantitatif dengan menggunakan metoda survey dengan kuesioner. Metoda ini dipilih dengan pertimbangan metoda ini bisa mengukur seberapa besar pengaruh suatu faktor terhadap keterlambatan proyek. Metoda kuesioner ini adalah metoda survey yang banyak dipakai dan bisa mendapatkan jumlah responden dalam jumlah banyak (Naoum, 2007; Saunders, Lewis, \& Thornhill, 2007).

Kegiatan awal dalam penelitian ini adalah menyusun kuesioner dengan menentukan faktorfaktor apa saja yang akan dimasukkan sebagai pertanyaan dalam kuesioner. Dalam penelitian ini sudah dilakukan kajian literatur terhadap keterlambatan proyek dan setelah analisa dan pengelohan literatur didapatkan 17 faktor keterlambatan yang akan menjadi pertanyaan utama di kuesioner (Tabel 3).

Tabel 3. Faktor - Faktor Penyebab Keterlambatan Proyek

\begin{tabular}{lll}
\hline $\begin{array}{l}\text { No } \\
.\end{array}$ & Kode & Faktor Penyebab Keterlambatan Proyek \\
\hline 1 & X1 & Tenaga ahli proyek yang kurang berpengalaman \\
\hline 2 & X2 & Terjadinya addendum kontrak \\
\hline 3 & X3 & Perencanaan metode konstruksi yang akan digunakan kurang tepat \\
\hline 4 & X4 & Kesalahan pengelolaan material \\
\hline 5 & X5 & Spesifikasi teknis yang tidak tepat \\
\hline 6 & X6 & Komunikasi dan kordinasi unsur proyek yang tidak berjalan baik \\
\hline 7 & X7 & Tidak menyiapkan peralatan yang tidak memadai untuk pelaksanaan proyek \\
\hline 8 & X8 & Tidak tepatnya waktu pembayaran yang diterima kontraktor \\
\hline 9 & X9 & Manajemen pengawasan proyek yang buruk \\
\hline 10 & X10 & Harga penawaran yang terlalu rendah dari kontraktor \\
\hline 11 & $\mathrm{X} 11$ & Kualitas pengendalian schedulle proyek konstruksi yang tidak baik \\
\hline 13 & X12 & $\begin{array}{l}\text { Kesulitan dalam proses mobilisasi dan demobilisasi karena lokasi proyek } \\
\text { sulit dijangkau }\end{array}$ \\
\hline 14 & X13 & Kondisi modal kerja penyedia jasa yang kurang baik \\
\hline 15 & Xeterlambatan akibat pengaruh cuaca \\
\hline 16 & X16 & Perubahan situasi atau kebijaksanaan politik/ ekonomi pemerintah \\
\hline 17 & X17 & Tidak adanya sosialisasi dengan Instansi terkait di lokasi pekerjaan dari \\
& & kontraktor sebelum proyek dimulai \\
\hline
\end{tabular}

Kuesioner disusun dalam format kertas (paper based questionnaire), dengan pertanyaan disusun dari penyebab keterlambatan yang sudah teridentifikasi pada Tabel 3. Pada kuesioner responden ditanyakan seberapa besar pengaruh faktor tersebut terhadap keterlambatan proyek dengan menggunakan skala rating 1 sampai 5. Skala 1 untuk sangat tidak berpengaruh sampai skala 5 sangat berpengaruh. 
Untuk responden yang mengisi kuesioner, dalam penelitian ini diambil dari pihak-pihak yang terlibat dalam proyek konstruksi sumberdaya air di Kabupaten Solok, dengan mengambil kasus proyek-proyek yang telah terlaksana pada tahun 2015 (lihat Tabel 1). Kuesioner yang diberikan kepada para Konsultan Perencana, Kontraktor, Konsultan Pengawas serta para staf Dinas Pekerjaan Umum, Pejabat Pelaksana Teknis Kegiatan (PPTK) dan Pejabat Pembuat Komitmen (PPK) yang terlibat dalam kegiatan proyek. Dari setiap kegiatan proyek di Tabel 1 ditetapkan responden 5 orang, dengan rincian dua orang dari pemilik (PPTK dan PPK), dan masing-masing satu orang dari konsultan pengawas, konsultan perencana, dan kontraktor. Sehingga total responden menjadi 75 orang. Metoda distribusi kuesioner menggunakan 'antar langsung dan tunggu', peneliti menmberikan langsung kuesioner ke responden, menjelaskan tentang penelitian kepada responden, dan selanjutnya menunggu dan mengambil kembali kuesioner dari responden. Sebagian besar responden menyelesaikan pengisian dalam waktu dua sampai empat hari. Dengan menggunakan metoda ini semua responden bisa selesai mengisi kuesioner tersebut $(100 \%$ kuesioner kembali).

Profil responden bisa dilihat pada Tabel 4 berikut. Dari profil tersebut terlihat hampir $55 \%$ responden mempunyai pengalaman selama 10-20 tahun mengerjakan proyek sumberdaya air di Kabupaten Solok, sehingga hasil penelitian ini bisa merefleksikan pelaksanaan proyek di Kabupaten Solok. Lebih jauh dari tabel terlihat ada dua macam kegiatan proyek sumberdaya air yang dilaksanakan, yaitu pekerjaan dam penahan tebing sungai dan pekerjaan saluran irigasi.

Tabel 4. Profil Respoden

\begin{tabular}{|c|c|c|c|}
\hline No & Karakterisituk Responden & Jumlah & $\begin{array}{l}\text { Persentas } \\
\text { e }\end{array}$ \\
\hline \multirow[t]{3}{*}{1} & Jenis Kelamin & & \\
\hline & . Laki-laki & 66 & $88 \%$ \\
\hline & - Perempuan & 9 & $12 \%$ \\
\hline \multirow[t]{7}{*}{2} & Usia Responden & & \\
\hline & . $<20$ Tahun & 2 & $2.67 \%$ \\
\hline & . 21 - 30 Tahun & 11 & $14.67 \%$ \\
\hline & . 31 - 40 Tahun & 25 & $33.33 \%$ \\
\hline & . 41 - 50 Tahun & 30 & $40.00 \%$ \\
\hline & . 51 - 60 Tahun & 7 & $9.33 \%$ \\
\hline & . $>60$ Tahun & 0 & $0.00 \%$ \\
\hline \multirow[t]{5}{*}{3} & Pendidikan & & \\
\hline & - SLTA & 21 & $28.00 \%$ \\
\hline & . Diploma & 3 & $4.00 \%$ \\
\hline & - Sarjana & 36 & $48.00 \%$ \\
\hline & - Pasca Sarjana & 15 & $20.00 \%$ \\
\hline \multirow[t]{6}{*}{4} & Pekerjaan & & \\
\hline & - Pegawai Dinas Pekerjaan Umum & 30 & $40.00 \%$ \\
\hline & . Konsultan Perencana & 15 & $20.00 \%$ \\
\hline & . Konsultan Pengawas & 15 & $20.00 \%$ \\
\hline & . Kontraktor & 15 & $20.00 \%$ \\
\hline & . Lain - Lain & 0 & $0.00 \%$ \\
\hline \multirow[t]{4}{*}{5} & Jenis Proyek Sumber Daya Air & & \\
\hline & - Dam Penahan Tebing Sungai & 20 & $26.67 \%$ \\
\hline & · Bendungan/Bendung & 0 & $0.00 \%$ \\
\hline & . Embung/Waduk & 0 & $0.00 \%$ \\
\hline
\end{tabular}




\begin{tabular}{llll}
\hline No & Karakterisituk Responden & Jumlah & $\begin{array}{l}\text { Persentas } \\
\text { e }\end{array}$ \\
\hline & & 55 & $73.33 \%$ \\
\hline 6 & Pengalaman di Proyek Sumber Daya Air di Kabupaten Solok & \\
\hline & 5 Tahun & 6 & $8.00 \%$ \\
\hline$\cdot 6-10$ Tahun & 28 & $37.33 \%$ \\
\hline$\cdot 11-15$ Tahun & 23 & $30.67 \%$ \\
\hline$\cdot 16-20$ Tahun & 18 & $24.00 \%$ \\
\hline$\cdot \quad>20$ Tahun & 0 & $0.00 \%$ \\
\hline
\end{tabular}

Setelah semua kuesioner terkumpul kemudian dilakukan pengolahan data menggunakan bantuan program Microsoft Excel. Kemudian dilanjutkan dengan analisa data dengan melakukan perhitungan statistik deskriptif, terutama menggunakan rata-rata untuk melihat seberapa besar suatu faktor akan berpengaruh terhadap keterlambatan proyek.

\section{HASIL DAN PEMBAHASAN}

Hasil pengolahan data diperlihatkan pada Tabel 5. Jawaban dikelompokkan menjadi jawaban kuesioner semua, gabungan, sejumlah 75 responden dan kemudian juga disajikan jawaban dari masing-masing kelompok responden.

Tabel 5. Faktor penyebab keterlambatan proyek sumberdaya air di Kabupaten Solok

\begin{tabular}{|c|c|c|c|c|c|c|c|c|c|c|c|c|c|}
\hline \multirow[t]{2}{*}{ No } & \multirow{2}{*}{$\begin{array}{l}\text { Fakt } \\
\text { or }\end{array}$} & \multicolumn{2}{|c|}{$\begin{array}{c}\text { Gabungan } \\
(\mathrm{n}=75)\end{array}$} & \multicolumn{2}{|c|}{$\begin{array}{c}\text { Konsultan } \\
\text { Perencana } \\
(\mathrm{n}=15)\end{array}$} & \multicolumn{2}{|c|}{$\begin{array}{c}\text { Konsultan } \\
\text { Pengawas } \\
(\mathrm{n}=15)\end{array}$} & \multicolumn{2}{|c|}{$\begin{array}{c}\text { Kontraktor } \\
(\mathrm{n}=15)\end{array}$} & \multicolumn{2}{|c|}{$\begin{array}{l}\text { PPTK } \\
(n=15)\end{array}$} & \multicolumn{2}{|c|}{ PPK $(n=15)$} \\
\hline & & $\begin{array}{l}\text { Rata } \\
\text {-rata }\end{array}$ & $\begin{array}{l}\text { Stde } \\
\mathbf{v}\end{array}$ & $\begin{array}{l}\text { Rata } \\
\text {-rata }\end{array}$ & $\begin{array}{l}\text { Stde } \\
\mathrm{v}\end{array}$ & $\begin{array}{l}\text { Rata } \\
\text {-rata }\end{array}$ & $\begin{array}{l}\text { Stde } \\
\text { v }\end{array}$ & $\begin{array}{l}\text { Rata } \\
\text {-rata }\end{array}$ & $\begin{array}{l}\text { Stde } \\
\text { v }\end{array}$ & $\begin{array}{l}\text { Rata } \\
\text {-rata }\end{array}$ & $\begin{array}{l}\text { Stde } \\
\mathrm{v}\end{array}$ & $\begin{array}{l}\text { Rata } \\
\text {-rata }\end{array}$ & $\begin{array}{l}\text { Stde } \\
\mathbf{V}\end{array}$ \\
\hline 1 & $\mathrm{X} 1$ & 4,07 & 0,79 & 3,80 & 0,68 & 4,13 & 0,64 & 4,07 & 0,80 & 4,27 & 0,80 & 4,07 & 1,03 \\
\hline 2 & $\mathrm{X} 2$ & 3,47 & 0,86 & 3,40 & 0,74 & 3,53 & 0,92 & 3,53 & 0,92 & 3,33 & 0,82 & 3,53 & 0,99 \\
\hline 3 & $\mathrm{X} 3$ & 3,89 & 0,92 & 4,07 & 0,70 & 3,80 & 0,94 & 4,07 & 0,80 & 3,73 & 1,10 & 3,80 & 1,08 \\
\hline 4 & $\mathrm{X} 4$ & 4,05 & 0,66 & 3,93 & 0,96 & 3,93 & 0,46 & 4,27 & 0,46 & 4,13 & 0,64 & 4,00 & 0,65 \\
\hline 5 & X5 & 4,12 & 0,79 & 4,07 & 1,03 & 4,07 & 0,59 & 4,40 & 0,63 & 3,93 & 0,80 & 4,13 & 0,83 \\
\hline 6 & $\mathrm{X} 6$ & 4,19 & 0,5 & 4,20 & 0,41 & 4,20 & 0,68 & 4,27 & 0,46 & 3,93 & 0,70 & 4,33 & 0,49 \\
\hline 7 & $\mathrm{X} 7$ & 4,01 & 0,6 & 3,67 & 0,82 & 4,00 & 0,76 & 4,13 & 0,35 & 4,07 & 0,46 & 4,20 & 0,68 \\
\hline 8 & X8 & 3,48 & 0,8 & 3,53 & 0,74 & 3,40 & 0,83 & 3,80 & 0,86 & 3,20 & 0,86 & 3,47 & 0,74 \\
\hline 9 & $\mathrm{X} 9$ & 4,20 & 0,5 & 4,27 & 0,46 & 4,27 & 0,59 & 4,2 & 0,56 & 4,13 & 0,52 & 4,13 & 0,74 \\
\hline 10 & $\mathrm{X} 10$ & 4,11 & 0,75 & 3,93 & 0,80 & 4,27 & 0,80 & 4,07 & 0,88 & 4,07 & 0,80 & 4,20 & 0,41 \\
\hline 11 & $\mathrm{X} 11$ & 3,83 & 0,74 & 3,73 & 0,80 & 3,73 & 0,80 & 3,87 & 0,52 & 4,07 & 0,70 & 3,73 & 0,88 \\
\hline 12 & $\mathrm{X} 12$ & 4,28 & 0,81 & 4,07 & 0,80 & 4,20 & 0,94 & 4,40 & 0,83 & 4,67 & 0,49 & 4,07 & 0,88 \\
\hline 13 & $\mathrm{X} 13$ & 4,03 & 0,75 & 4,07 & 0,88 & 3,80 & 0,86 & 4,27 & 0,59 & 4,00 & 0,65 & 4,00 & 0,76 \\
\hline 14 & X14 & 4,53 & 0,62 & 4,40 & 0,63 & 4,60 & 0,63 & 4,40 & 0,74 & 4,73 & 0,46 & 4,53 & 0,64 \\
\hline 15 & X15 & 3,57 & 1,00 & 3,40 & 1,12 & 3,60 & 1,12 & 3,80 & 1,15 & 3,47 & 0,99 & 3,60 & 0,63 \\
\hline 16 & $\mathrm{X} 16$ & 4,53 & 0,62 & 4,47 & 0,64 & 4,53 & 0,83 & 4,53 & 0,64 & 4,60 & 0,51 & 4,53 & 0,52 \\
\hline 17 & $\mathrm{X} 17$ & 4,37 & 0,59 & 4,00 & 0,76 & 4,53 & 0,52 & 4,47 & 0,52 & 4,40 & 0,51 & 4,47 & 0,52 \\
\hline
\end{tabular}

Dari keseluruhan responden, 5 faktor utama yang berpengaruh terhadap keterlambatan adalah faktor X16 (pembebasan tanah, rata-rata 4,53), X14 (pengaruh cuaca, rata-rata 4,53), X17 (tidak ada sosialisasi dengan instansi terkait, rata-rata 4,37), X12 (lokasi proyek sulit dijangkau, rata-rata 4,28), dan X9 (manajemen pengawasan proyek yang buruk, rata-rata $4,20)$.

Dalam penelitian ini menghasilkan temuan faktor pembebasan lahan dan cuaca menjadi faktor dengan pengaruh terbesar sebagai penyebab keterlambatan proyek sumberdaya air di 
Kabupaten Solok. Hasil penelitian ini selaras dengan temuan Hidayat and Rasadi (2014) yang memperlihatkan faktor lahan menjadi risiko terbesar proyek, setelah risiko berkaitan tender, di Sumatera Barat. Dalam penelitian ini ditemukan adanya kasus pemblokiran lokasi proyek oleh warga dikarenakan adanya tuntutan ganti rugi oleh masyarakat tidak terpenuhi. Penelitian Nengsi (2019) tentang risiko proyek bidang pengairan juga memperlihatkan faktor pembebasan lahan menjadi risiko yang terbesar. Masalah pembebasan tanah di Sumatera Barat tergolong rumit karena sebagian tanah masyarakat merupakan tanah kaum atau tanah ulayat, bukan tanah pribadi, sehingga menyangkut banyak pihak. Pembebasan lahan bisa memakan waktu yang cukup lama. Hasil penelitian ini juga memperlihatkan hasil yang mirip dengan penelitian Masita and Adi (2015), dimana mereka meneliti faktor penyebab keterlambatan proyek sumberdaya air di Provinsi Papua. Hasil penelitian mereka memperlihatkan faktor ganti rugi lahan, lemahnya pengawasan, dan keterlambatan pengiriman material sebagai tiga faktor utama penyebab keterlambatan proyek (Masita \& Adi, 2015). Permasalahan lahan menjadi faktor penting yang perlu diselesaikan sebelum dimulainya suatu proyek, karena tanah yang belum bebas akan dapat menghambat pelaksanaan pekerjaan, atau bahkan bisa menyebabkan pekerjaan proyek tidak dapat diselesaikan sesuai target jadwal (Istijono, 2014).

Selain faktor pembebasan lahan, dari penelitian ini ditemukan faktor cuaca adalah salah satu faktor tertinggi (nilai rata-rata 4,53) sebagai penyebab keterlambatan proyek di Kabupaten Solok. Intensitas curah hujan yang tinggi dan turunnya hujan tidak dapat diprediksi membuat pekerjaan jadi terhambat. Hasil data curah hujan di Kabupaten Solok memperlihatkan puncak musim hujan berlangsung pada bulan Desember sampai Februari setiap tahunnya. Apabila terjadi hujan, pekerjaan beton seperti pengerjaan pasangan batu kali dan pengecoran tidak dapat dilakukan, karena jika terus dilakukan maka berdampak pada mutu pekerjaan menjadi rendah.

Faktor penyebab keterlambatan berikutnya adalah tidak adanya sosialisasi dengan instansi terkait dilokasi pekerjaan dari kontraktor sebelum proyek dimulai, berada pada posisi tiga dengan nilai rata-rata berdasarkan kuesioner 4,37. Sosialisasi dengan instansi terkait adalah kunci awal bagi keberhasilan kerja dalam pelaksanaan proyek konstruksi, sosialisasi memerlukan komunikasi yang baik agar tidak terjadi permasalahan dalam pelaksanaan proyek. Sebelum memulai pekerjaan terlebih dahulu harus membuat surat pemberitahuan mulai pekerjaan kepada Camat, Kapolsek, Wali Nagari, Kepala Jorong, Ketua Pemuda dan instansi lainnya. Komunikasi yang baik dengan masyarakat bisa mengurangi hambatan dalam pelaksanaan proyek. Seperti perlihatkan pada penelitian Andria, Afrizal, and Azwar (2018), komunikasi yang baik oleh pemda ke masyarakat membuat persoalan pembebasan lahan di proyek jalan Bypass Kota Padang menjadi berkurang.

Dari tabel 5, faktor X12 kesulitan mobilisasi karena proyek sulit dijangkau berada pada peringkat 4 faktor penyebab keterlambatan dengan nilai rata-rata 4,28. Lokasi proyek pengairan sebagian besar di pelosok, tidak ada jalan akses, sehingga menyulitkan dalam membawa material dan peralatan ke lokasi proyek. Material proyek dibawa ke lokasi proyek dengan menggunakan truk sampai dengan jalan terdekat lokasi proyek. Selanjutnya material dibawa menggunakan tenaga manusia atau menggunakan motor ke lokasi proyek pengairan tersebut. 

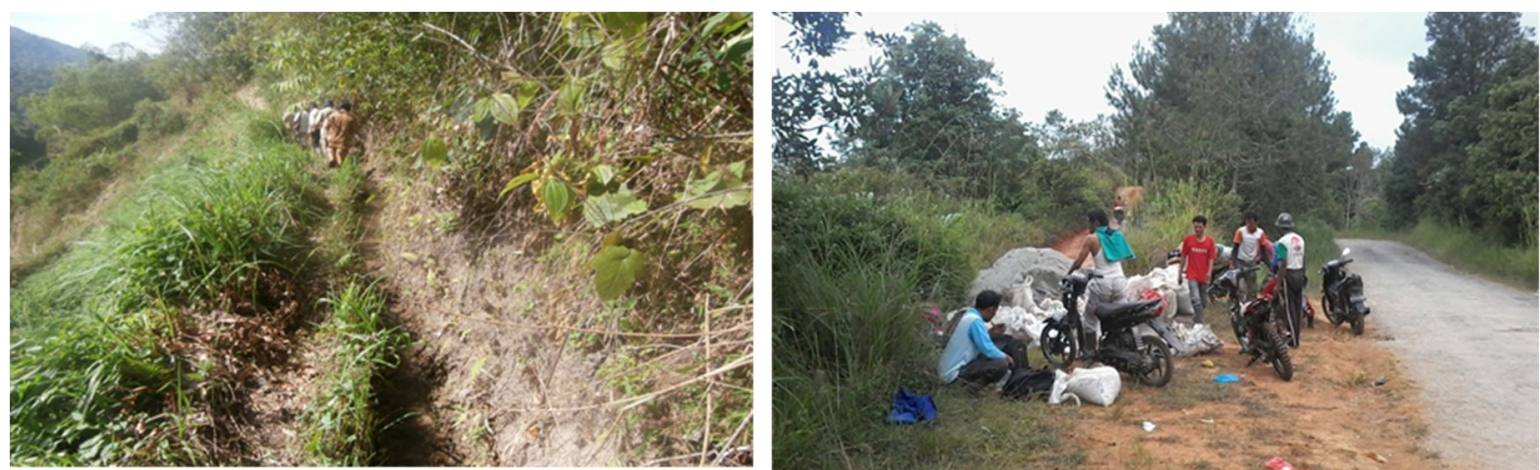

Gambar 1. Lokasi proyek dan mobilisasi material ke lokasi proyek

Di peringkat kelima faktor penyebab keterlambatan proyek pengairan di Kabupaten Solok adalah faktor manajemen pengawasan proyek yang buruk (X9) dengan nilai rata-rata persepsi hasil kuesioner adalah 4,2. Ini disebabkan oleh pengawas proyek yang kurang berpengalaman terhadap pekerjaan, perhitungan keperluan bahan, perubahan desain. Juga keterlambatan disebabkan karena komunikasi yang kurang baik antara kontraktor dan konsultan pengawas, serta kurangnya persiapan atau penetapan rancangan tempat pelaksanaan setiap item pekerjaan.

Tabel 5 memperlihatkan hasil kuesioner, nilai rata-rata pengaruh faktor terhadap keterlambatan proyek. Pada tebal tersebut disajikan hasil persepsi seluruh responden dan juga ada hasil berdasarkan kelompok kuesioner, terdiri dari kontraktor, konsultan perencana, konsultan pengawas, kontraktor, PPTK, dan PPK. Pemeriksaan awal memperlihatkan adanya perbedaan persepsi antar responden mengenai faktor penyebab keterlambatan, dengan adanya nilai rata-rata yang cukup berbeda diantara responden. Data pada tabel 5 kemudian dijadikan grafik garis, seperti tersaji pada Gambar 2.

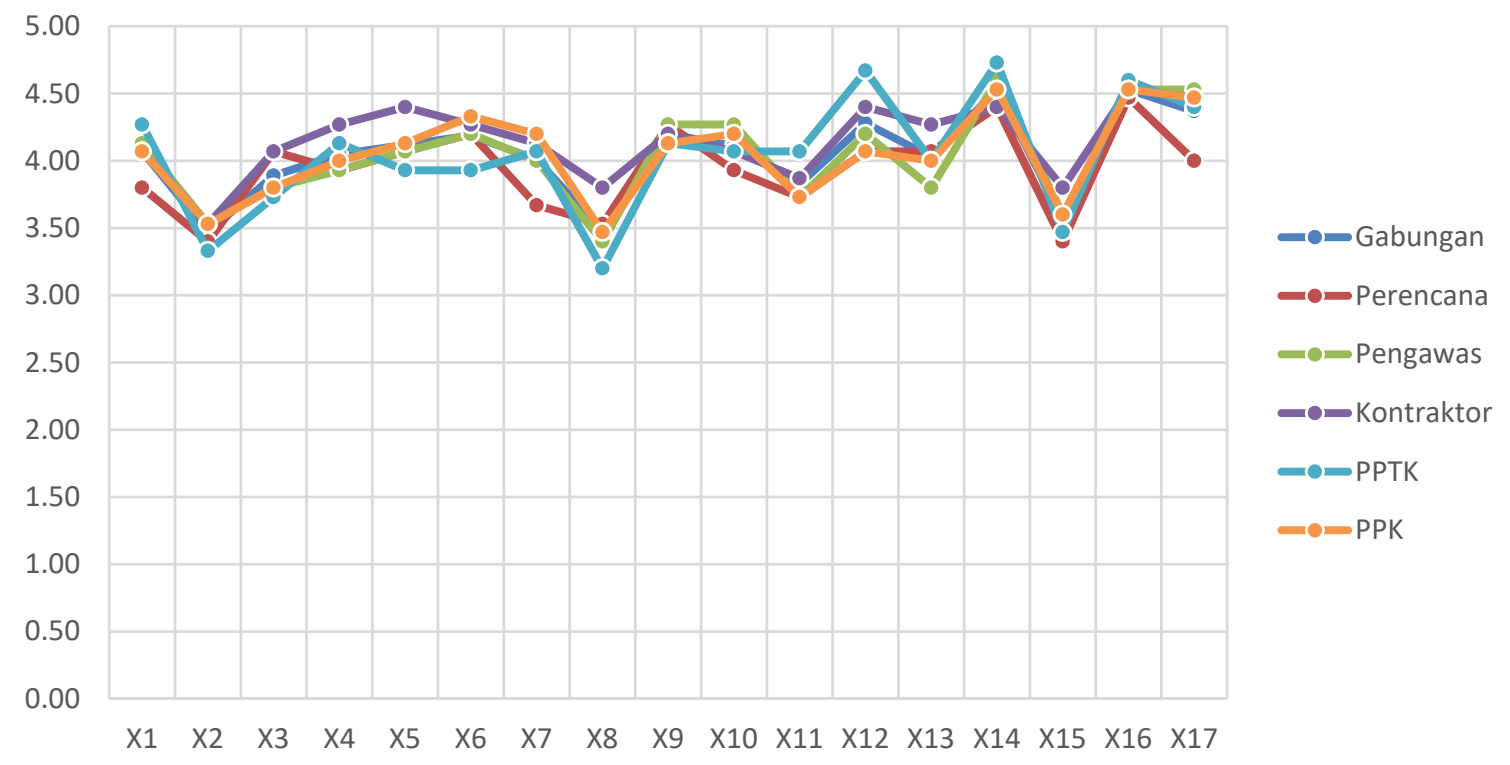

Gambar 2. Faktor penyebab keterlambatan proyek sumberdaya air 
Gambar 2 di atas memperlihatkan adanya perbedaan persepsi antara kontraktor sebagai pelaksana pekerjaan dengan konsultan dan pemilik. Kontraktor mempunyai nilai rata-rata tertinggi dibandingkan dengan responden lain di faktor X3 (metoda konstruksi kurang tepat), X4 (kesalahan pengelolaan material, X5 (spesifikasi teknis tidak tepat), X8 (tidak tepatnya waktu pembayaran), X13 (kondisi modal kerja), dan X15 (perubahan situasi politik dan ekonomi). Hasil kuesioner dari responden kontraktor kemudian dibandingkan dengan responden lain, disajikan pada Tabel 6. Angka positif artinya hasil kuesioner kontraktor lebih besar, dan sebaliknya jika negatif maka hasil kuesioner kontraktor lebih kecil dari kelompok responden lain yang dibandingkan. Untuk memperlihat perbedaan yang berarti, pada tabel tersebut perbedaan yang melebihi 0,25 ditandai dengan tulisan tebal dan miring.

Tabel 6. Perbandingan nilai rata-rata kuesioner kontraktor dengan responden lain

\begin{tabular}{|c|c|c|c|c|}
\hline Faktor & $\begin{array}{c}\text { Kontraktor } \\
\text {-PPTK }\end{array}$ & $\begin{array}{c}\text { Kontraktor } \\
\text {-PPK }\end{array}$ & $\begin{array}{l}\text { Kontraktor } \\
\text {-Perencana }\end{array}$ & $\begin{array}{l}\text { Kontraktor } \\
\text {-Pengawas }\end{array}$ \\
\hline $\mathrm{X} 1$ & $-0,20$ & 0,00 & 0,27 & $-0,06$ \\
\hline $\mathrm{X} 2$ & 0,20 & 0,00 & 0,13 & 0,00 \\
\hline $\mathrm{X} 3$ & 0,34 & 0,27 & 0,00 & 0,27 \\
\hline $\mathrm{X} 4$ & 0,14 & 0,27 & 0,34 & 0,34 \\
\hline $\mathrm{X} 5$ & 0,47 & 0,27 & 0,33 & 0,33 \\
\hline $\mathrm{X} 6$ & 0,34 & $-0,06$ & 0,07 & 0,07 \\
\hline $\mathrm{X} 7$ & 0,06 & $-0,07$ & 0,46 & 0,13 \\
\hline $\mathrm{X} 8$ & 0,60 & 0,33 & 0,27 & 0,40 \\
\hline $\mathrm{X9}$ & 0,07 & 0,07 & $-0,07$ & $-0,07$ \\
\hline $\mathrm{X} 10$ & 0,00 & $-0,13$ & 0,14 & $-0,20$ \\
\hline $\mathrm{X} 11$ & $-0,20$ & 0,14 & 0,14 & 0,14 \\
\hline $\mathrm{X} 12$ & $-0,27$ & 0,33 & 0,33 & 0,20 \\
\hline $\mathrm{X} 13$ & 0.27 & 0.27 & 0.20 & 0.47 \\
\hline $\mathrm{X} 14$ & -0.33 & -0.13 & 0.00 & -0.20 \\
\hline $\mathrm{X} 15$ & 0.33 & 0.20 & 0.40 & 0.20 \\
\hline $\mathrm{X} 16$ & -0.07 & 0.00 & 0.06 & 0.00 \\
\hline $\mathrm{X} 17$ & 0.07 & 0.00 & 0.47 & -0.06 \\
\hline
\end{tabular}

Tabel di atas memperlihatkan adanya perbedaan yang berarti di hasil kuesioner kelompok responden kontraktor dengan yang lain di faktor X5 (spesifikasi teknis tidak tepat), X8 (tidak tepatnya waktu pembayaran). Persepsi kontraktor dua faktor tersebut mempunyai pengaruh yang besar terhadap keterlambatan proyek, sementara menurut kelompok responden lain tidak. Ini disebabkan karena faktor spesifikasi dan pembayaran berada di luar ranah kewewenangan dan pengendalian dari kontraktor, lebih ke wewenang pemilik dan konsultan. Hasil ini mengindikasikan adanya kesulitan kontraktor dalam pelaksanaan pekerjaan yang disebbakan oleh ketidaktepatan spesifikasi dan keterlambatan pembayaran oleh pemilik.

\section{KESIMPULAN DAN SARAN}

Penelitian ini bertujuan untuk mengidentifikasi sumber-sumber penyebab keterlambatan proyek infrastruktur sumberdaya air di Kabupaten Solok. Dari 17 buah faktor yang ditinjau, dari hasil kuesioner dengan 75 responden didapatkan 5 faktor utama yang berpengaruh 
terhadap keterlambatan, yaitu pembebasan tanah (nilai rata-rata 4,53), pengaruh cuaca (rata-rata 4,53), tidak ada sosialisasi dengan instansi terkait (rata-rata 4,37), lokasi proyek sulit dijangkau (rata-rata 4,28), dan manajemen pengawasan proyek yang buruk (rata-rata 4,20 ). Hasil kuesioner juga memperlihatkan adanya perbedaan persepsi yang cukup berarti antara kontrator dengan responden lain, yaitu di faktor keterlambatan akibat ketidaktepatan spesifikasi dan keterlambatan pembayaran.

Hasil penelitian ini memperlihatkan perlunya adanya perencanaan yang lebih baik untuk proyek sumberdaya air, khususnya di Kabupaten Solok. Lokasi yang sulit dijangkau, lahan yang juga sulit dibebaskan, dan pengaruh cuaca membuat lokasi pekerjaan proyek menjadi faktor penyebab utama keterlambatan, dan ini memerlukan persiapan dan perencanaan yang lebih lama.

\section{DAFTAR PUSTAKA}

Andria, R., Afrizal, \& Azwar. (2018). Komunikasi Antarpribadi Pada Pembebasan Lahan Proyek Padang ByPass. Jurnal Rekayasa Sipil (JRS-Unand), 18(2), 95-106. doi:https://doi.org/10.25077/jrs.14.2.95-106.2018

BPS Kab. Solok. (2017). Luas Tanam Tanaman Padi Sawah. Retrieved from https://solokkab.bps.go.id/dynamictable/2017/05/22/10/luas-tanam-tanaman-padisawah.html

Hidayat, B., \& Rasadi, A. (2014). Studi risiko proyek konstruksi di Sumatera Barat dengan metoda content analysis artikel berita surat kabar. Paper presented at the Konferensi Nasional Teknik Sipil 8 (Konteks 8), Bandung, Jawa Barat. 16-18 Oktober 2014.

Istijono, B. (2014). Lahan Menjadi Faktor Penghambat Dalam Pelaksanaan pembangunan Untuk Kepentingan Umum. Jurnal Rekayasa Sipil (JRS-Unand), 1O(2), 52-59. doi:https://doi.org/10.25077/jrs.10.2.52-59.2014

Kerzner, H. (2009). Project Management. A system approach to planning, schedulling, and controlling (10th ed.) (10 ed.). New York: John Wiley \& Sons.

Masita, R. N., \& Adi, T. J. W. (2015). Faktor-Faktor Penyebab Keterlambatan Proyek Di Bidang Sumber Daya Air Dinas Pekerjaan Umum Provinsi Papua. Paper presented at the Seminar Nasional Manajemen Teknologi XXII, Surabaya - 24 Januari 2015.

Naoum, S. G. (2007). Dissertation research and writing for construction students (2nd ed.). Oxford, UK: Butterworth-Heinemann.

Nengsi, D. P. (2019). Studi Persepsi Risiko Pada Proyek Konstruksi Bidang Pengairan di Sumatera Barat. (Magister), Tesis, Magister Teknik Sipil, Universitas Andalas, Padang. Retrieved from http://scholar.unand.ac.id/56112/

Pemkab. Solok. (2009). Geografis Kabupaten Solok. Retrieved from https://solokkab.go.id/halkeadaan-geografis-kabupaten-solok.html

PMI. (2008). A guide to the project management body of knowledge (PMBOK Guide) - Fourth edition. Newton Square, Pennsylvania: Project Management Institute, Inc.

Saunders, M., Lewis, P., \& Thornhill, A. (2007). Research method for business students (4th ed) (Fourth ed.). Essex: Pearson education.

Soeharto, I. (1995). Manajemen Proyek - Dari Konseptual Sampai Operasional. Jakarta: Penerbit Erlangga. 